\title{
From invisible to visible: Locating 'cultural expertise' in the law courts of two Finnish cities
}

\author{
Taina Cooke \\ Department of Cultural Anthropology \\ University of Oulu, Finland
}

\begin{abstract}
In this chapter, I examine the informal cultural expertise utilised in the District Courts and Courts of Appeal of two Finnish cities. I argue that the parties that serve as providers of 'cultural expertise' are manifold, and include eyewitnesses, interpreters and even the courts themselves. I examine the challenges regarding the informal use of cultural expertise, drawing from debates that consider the relationship between an 'insider expert' and a 'trained expert' in acting as a cultural mediator.
\end{abstract}

Keywords: court ethnography, cultural expertise, cultural minorities, eyewitnesses, Finland, interpreters 


\section{Introduction}

"If we talk about people from, let's say, the Middle East, we tend to have stereotypes about them that are based on our prejudices rather than actually knowing them and surely that applies - - I mean the District Courts and the members of law courts are in no way cut off from the general life, it applies to them, too. [- - - It is clear that if we talk about, for example, homicide to which the defendant has pleaded not guilty and it is argued that the meanings of all the important factors would be completely different if the crime was committed among Finns than if it was committed among immigrants, then the only way [to find out about the crime] is to invite an expert witness to explain the cultural issues. However, in no trial, so far, have I invited [an expert witness] nor have I been to one where one was invited; although in principle it could happen in any case."

(Interview, lawyer)

The interview I conducted during a one-and-half-hour drive to the District Court in a nearby town with a Finnish criminal defence lawyer was a peculiar mix of cynicism and cautious optimism. The lawyer, who had practised law for 23 years, was no stranger to clients from cultural minorities, and he seemed to become passionate when we first entered the discussion around 'culture talk' in courts. He seemed to be of the opinion that information around different cultures and their practices could come in useful in some cases. Moreover, according to him, lawyers should play a key role in introducing such new ideas into a legal system that is often slow to change. Yet, in the next breath, he stated that he was frustrated with the rigidity of the system. Theoretically, one can try to raise all sorts of defences, but it often feels like in the end nothing is accepted. I got the strong feeling that in the lawyer's mind the idea of cultural expertise reflected the same frustration: a nice idea in theory but hardly applicable in legal practice. 
This chapter discusses the potential of cultural expertise in the legal sphere and examines the complexities regarding the notion of culture. In order to address the cross-cultural challenges increasingly occurring in European and American legal practices, several scholars have examined the potential of so-called cultural expertise (Ballard 2011, Good 2011, Holden 2011a, Menski 2011, Vatuk 2011). As Western legal practitioners are presently dealing with litigation involving cultural traits largely unknown to them, it has been suggested that further assistance from anthropologists or other cultural experts might come in useful (Holden 2011a: 1, Renteln 2004, Van Broeck 2001, Winkelman 1996). In Finland, expert witnessing was one of the focal points in a 2016 legal reform concerning the law of evidence; however, discussions on the role of cultural expertise appear to remain minimal. Despite the fact that culture or cultural expertise does not enjoy a formally recognised position in Finnish litigation, cultural argumentation does arise and receive attention in legal proceedings.

In this chapter, I will provide a brief introduction to the national legislative framework concerning expert witnessing in Finland. I will introduce examples from my own data relating to the use of informal cultural expertise in the legal sphere, and examine whose views and knowledge matter when seeking to verify traits regarding a person's 'culture' in court. Furthermore, I will analyse the discursive methods applied by the courts in their verdicts in making cultural information applicable for their use. I will look into the appointment of a community member as a cultural expert and consider the relationship between an 'insider expert' and a 'trained expert' in legal cases involving cultural minorities. Furthermore, I will speculate on the conceptual challenges that may follow when 'culture' is harnessed for legal purposes. Cultural expertise is hardly objective and never unburdened by the vexed anthropological questions regarding the nature of culture, but its potential in steering the legal discussions regarding cultural minority members in a direction that is more transparent and informed is worth considering. 
The treatment of culture in legal arenas is worth studying as there appear to be no shared practices or guidelines on how to deal with cultural arguments in court. It is important to shed light on 'culture talk' that, nevertheless, does occur in court and potentially impacts the legal outcomes of cases involving cultural minority members. The level of awareness concerning cultural issues among legal professionals, in my experience, varies wildly. It can be argued that the assessments of cases involving cultural minority representatives tend to lend themselves to highly stereotypical and dichotomous notions in legal arenas, resulting in the renewal and validation of this simplifying imagery in the process (Bhaba 2006, Noll 2006, Spijkerboer 2005). This chapter is an attempt to highlight some of the ways in which 'cultural expertise' is now kept invisible in the legal sphere, yet still utilised by the courts. It will also look into some possible methods that could be of use in transforming 'culture talk' and making it more explicit.

\section{Finland and cultural expertise in courts - A brief overview}

The Finnish legal system can be regarded as a part of Nordic (or Scandinavian) law, which in turn is classified among the broader legal tradition of civil (or Roman-German) law (Husa 2012: 5, 12). Nordic law is close to civil law, but its lack of extensive private law codification as well as its pragmatic rather than highly theoretical nature distinguishes it from the traditional civil law legal family (Husa 2012: 8-12). In terms of Finnish criminal law and the criminal justice system, the Nordic view stresses a rational and humane approach (Melander 2012: 238). Finland has one of the smallest prison populations in Europe, and there is a clear emphasis on a cost-conscious and preventative outlook. The role of expert knowledge in court has been rather ambiguous until the beginning of 2016 when legislation reforming the law of evidence was introduced. Before the reform, a distinction between an expert witness and a witness with expert knowledge was made: the former was deemed more credible and could only be named by the court, whereas the latter could be appointed by the prosecutor or lawyers (Rautio and Frände 2016). At present, the division no 
longer exists, most likely resulting in the increased employment of expert witnesses and also homogenised credibility standards. Regardless of the recent heightened interest surrounding expert witnessing, however, the attention received by cultural expertise appears to be limited.

In some countries, such as South Africa and Australia, the long history of indigenous law has meant that cultural arguments have received recognition also in the national legal systems (cf. Bronitt 2009, Carstens 2009). Recognition of Finland's indigenous population, the Sámi people, and their traditional rights and cultural status in the legal sphere is a sensitive issue (e.g. Heinämäki et al 2017, Kokko 2010). There is no far-reaching institution of a specific 'Sámi law', but rather the ambition in the Nordic countries has for centuries been to assimilate the indigenous population as part of the general national legislation and jurisdiction. Being recognised as Sámi, then, has historically not guaranteed access to special treatment in the eyes of the law. The legal status of the Sámi minority has improved during recent decades and their rights to "maintain and develop their own language and culture", for example, was added to the Finnish Constitution in $1999(\S 17)$. However, disputes over land rights in particular are on-going and reflect the reluctance of the state to recognise the Sámi people as an indigenous population with clearly distinct special legal rights. Against this backdrop, it seems understandable that cultural expertise has not developed as a recognised feature of Finnish courtrooms so far.

According to my research data and several informal discussion with different legal professionals, cultural expertise is not commonly sought after in Finnish criminal cases involving cultural minority members, nor is there any established provider of such information generally known among legal professionals. This, however, does not mean that cultural arguments are absent from litigation. As I will demonstrate next, courts can place seemingly unbiased parties to the litigation, such as eyewitnesses and interpreters, into the roles of informal cultural experts. Sometimes, courts seem to merely rely on their own views when debating culture. Overall, it seems that cultural 
expertise does not find its way into Finnish courtrooms as much through the official channels as through the agency of informal 'cultural brokers'.

\section{Talking culture in court}

The examples presented here serve to demonstrate some of the varied negotiations regarding cultural issues in criminal cases that have taken place in Finnish courts. All but one example are from cases in which I have participated myself: 35 in total, in the District Court and the Court of Appeal in one of Finland's largest cities. The lengths of these trials have varied from approximately two hours to fifteen days. The population of the city is predominantly Finnish (96\% in 2015) yet the number of foreign nationals has increased steadily in recent years. The examples, while each relating to different crimes, represent the larger group of legal cases involving members from cultural minorities. The number of these cases has increased along with the related changes in population, yet they still display a clear minority of all the legal cases managed by the District Court and the Court of Appeal. For the cases I have participated in, I have made use of rich ethnographic data as well as the final court verdicts. The ethnographic data consists of extensive notes I have taken either during the trial or right after it, while the written verdicts are produced by courts and are often more concise in nature. For the one example that is not from a case dealt with in this particular city, I have only the written verdict. However, the length of the verdict, around 200 pages, as well as the heightened attention paid to cultural factors in it, make it a valuable source of data for research in cultural expertise. In addition to the court material, I have conducted five indepth interviews (two prosecutors, a judge, an interpreter and a lawyer) to complement the data. All the quotes presented here are my translations from Finnish to English. 
$\underline{\text { Mr Amin and a case of attempted manslaughter }}$

A case, tried in spring 2016, involved a young Kurdish man, Mr Amin, who arrived in Finland in 2015 to seek asylum. He lived in a reception centre with several other Kurds, with whom he often passed the time by playing pool in the basement of the building. One day, when a group of them were playing in the basement, two of the men, Mr Amin and Mr Rahimi, got into a fight. The situation escalated quickly: both of the men started verbally insulting the other's mother and sisters, after which the fight turned violent. The rest of the group made an effort to calm the situation, but with little success as, in the end, Mr Amin stabbed Mr Rahimi with a pair of small scissors in the neck area several times. As a result, Mr Amin was remanded in custody until trial and Mr Rahimi survived with fairly minor injuries.

At the trial, both the prosecutor and Mr Rahimi's lawyer asked the court to find Mr Amin guilty of attempted manslaughter whereas the defence insisted that Mr Amin had only committed an assault at most. The defence maintained that both parties were involved in a reciprocal assault and that $\mathrm{Mr}$ Amin had only used the scissors as a result of strong provocation on Mr Rahimi's part. In order to determine whether the conviction would be attempted manslaughter or assault, the court had to scrutinise Mr Amin's motives and decide if he was likely to have attempted to kill Mr Rahimi. In the process of examining Mr Amin's mindset, a number of culture-specific features of the incident were brought up and received a fair amount of attention during the litigation.

In court, Mr Rahimi, Mr Amin and a third Kurdish man, who was present at the time of the incident, all provided their oral testimonies. They shared similar views with regard to what triggered the violence, as they explained to the court that both parties were insulting each other's family members and, as the witness stated, in their culture offending someone's mother or sisters is the worst kind of offence, making it "a matter of honour". Mr Rahimi seemed surprised about $\mathrm{Mr}$ 
Amin's decision to attack him so violently, and explained: "We share a language and the same country, it's not like he is an Arab or anyone like that. He is a Kurd and we understand each other."

In order to scrutinise Mr Amin's motives and the possible intention to kill, the prosecutor and $\mathrm{Mr}$ Rahimi's lawyer were particularly interested in the death threats that were presented during the incident. The defence claimed that Mr Amin had threatened to kill Mr Rahimi in the process of the incident. Mr Amin was asked by the prosecutor detailed questions about the number and timing of the threat or threats: "How many times did you threaten to kill Mr Rahimi? Did this happen before, during or after the attack?" Mr Amin seemed confused about the level of interest in terms of verbal threats and could not provide particularly detailed responses. He also added that Mr Rahimi had, likewise, threatened to kill him. With the purpose of further clarifying the situation, the prosecutor also confronted the eyewitness about the nature of the threats. After several questions regarding the subjects and objects of the threats, the number of threats and their timing, the witness also appeared perplexed. In the end, the witness decided to shed light on the affair and offered his interpretation of the situation. He stated that in their culture when someone threatens to kill another person, it is most often just "a habit" and does not indicate an actual desire to kill. The witness continued: "I can give you an example. As children, when we played outside, mother would call to us, and she might shout 'Come in or I'll kill you!' It's just a habit, it doesn't mean anything serious."

In the end, Mr Amin escaped the charge of attempted manslaughter and he was convicted of a serious assault. The District Court sentenced Mr Amin to just under three years imprisonment, in addition to which he was required to pay damages. Later, the Court of Appeal accepted the District Court's verdict, for the most part, but reduced the sentence by one year. It appears that the courts did take the cultural argumentation into account when assessing the incident as the District Court's verdict states the following:

“It has become clear from the plaintiff's, defendant's and witness's narratives that both the defendant and the plaintiff have insulted each other's close relatives. In 
addition to this, at least the defendant has told the plaintiff that he intends to kill him. Then again, it has been told that in the defendant's and plaintiff's culture claiming to kill someone without having a real intention to do so, is rather easily done. The court deems that the cultural background of the defendant and the plaintiff shall be taken into account when assessing the significance of the statements, yet there has been no external report presented in this case regarding the way in which these sorts of statements should be interpreted in their culture. According to the witness, in their culture one can insult religion but never close relatives. In any case, both the defendant and the plaintiff are Kurds, therefore they share the same cultural background and they, in all likelihood, understand each other in the same way."

(Court verdict, p. 8)

In the verdict, the court stated that it had not been presented with any external report that would guide it in interpreting what were understood as cultural arguments in the case. Yet, as the sentence following that statement demonstrates, the witness ended up acting as a provider of cultural expertise in the litigation. According to the District Court's verdict, the witness had only arrived to the reception centre a couple of days prior to the incident in question, and that "He is also a Kurd" (p. 4). His recent arrival must have appeared significant to the court as they made a point of it, and it arguably served to lay the foundations for regarding the witness as credible and also unbiased to a large extent. Furthermore, the video material available of the incident (the reception centre had video surveillance in its premises) showed that the witness acted calmly during the episode and even made some efforts to separate the two men in order to prevent the violence from escalating. The witness' account played a key role in helping court assess what had taken place and for what reasons (the video material did not cover the whole incident and it lacked sound) as in the final verdict the witness' description was often raised when drawing conclusions on the episode. 
It is reasonable to assume that the credibility of the witness, established by the court, increased also the validity of the cultural arguments confirmed and presented by him in the case. As stated above, in its verdict the court reasons: "According to the witness, in their culture one can insult religion but never close relatives." Consequently, the court did seem to accept that the incident escalated quickly due to the highly offensive nature of these insults in "their culture". I suspect that it was ultimately the witness' verification regarding the casualness of death threats in 'Kurdish culture' that also convinced the court of the less serious nature of the verbal threats in the case. Due to his composed nature during both the violent incident and the court hearing, as well as his status as a seemingly unbiased 'insider', the witness appeared credible in the role of a cultural expert, even when the court did not formally recognise him as such.

\section{Human trafficking and forced labour in Oriental restaurants}

A quite unusual case came to trial first in the District Court and later also in the Court of Appeal of a Southern Finnish city in 2012. In studying this case, I relied on the 200-page document that includes both of the courts' final verdicts. The case involved a couple who originated from Vietnam but who had lived in Finland already for at least ten years. The couple developed a habit of recruiting employees from Vietnam to their Oriental restaurants in a Finnish city. Initially, the kitchen workers, ten in total, were promised better working conditions than what they really experienced: they worked extremely long hours for very low pay. Most of the employees lived in the employers' house, which was overcrowded, and the little free time they had, was more or less supervised by the couple. The workers also became indebted to the couple, which made the relationship even more pressing for the employees. The workers, who had no Finnish language skills or knowledge about their rights, worked for the couple for periods varying from ten months to six years before the employers were arrested. 
In the verdicts, both the District Court and the Court of Appeal considered the cultural backgrounds of the parties. Throughout the verdicts, statements are made regarding 'Vietnamese culture' and its connection to the relationship between the employers and workers as well as to the ways in which the plaintiffs acted in court. It was explained, for example, that in 'Vietnamese culture', the hierarchy between boss and worker means that questioning the actions of the employer is extremely difficult. Also, it was explained by the defendants in particular that the workers were offered a chance to be flown back to Vietnam if they no longer wished to work in the restaurants. The reluctance of the workers to leave, however, was explained through cultural factors: the risk of 'losing face' if they returned home empty handed prevented them from leaving. The influence of 'Vietnamese culture' was also highlighted when it was explained that the employees had to send money to their homes in Vietnam and, as a result of that, ran into debt with the employers.

Moreover, it was stated that because it was unusual in 'Vietnamese culture' to openly show emotions, the fact that the plaintiffs cried in court, was to be taken as an indication of them talking about particularly traumatic experiences.

Arguments relating to 'Vietnamese culture' were, then, certainly raised during the litigation as they also feature strongly in the written verdicts. But whose knowledge do the courts rely on when they make statements about 'Vietnamese culture'? In the written verdicts, there does not seem to be just one source of cultural information the courts systematically depend on, and, as I will demonstrate later, on occasion they appear to mainly trust their own understanding. There was, however, one party to the criminal hearing that, according to my interpretation, ended up assuming the position of an informal cultural expert, namely the witness. In the verdict, the witness is introduced as follows:

"According to XX, who is called to testify, her mother is Vietnamese and father Finnish. When she was one year old, she moved from Vietnam to Finland, where she has lived both with her mother and her father. When living with her mother, she has 
become familiar with Vietnamese culture. XX understands and is able to communicate in Vietnamese."

(Court verdict, p. 126)

Only after this initial introduction, it is explained how the witness is connected to the case at issue: she worked in one of the restaurants as a waitress for six weeks. I find it quite noteworthy and exceptional, however, that her 'cultural connection' to the case is highlighted before disclosing the actual reason for her being called to testify. This, I argue, highlights her dual role in the case as both a 'cultural broker' and an ordinary witness. It can be further argued that her status as a FinnishVietnamese person, who has grown up under cultural influences from both of the countries, appeared as an ideal cultural interpreter in the case. The witness was regarded as being sufficiently close to all the parties present at the trials and so was eventually entrusted with carrying the greatest share of the cultural gap in the cases and act a mediator. Within the two-and-a-half-page summary of the witness' account of what she had seen and heard during her short employment in the restaurant, there is also a paragraph stating the following:

“In Vietnamese culture, speaking out about grievances is not commonplace. [- - - ] Vietnamese people had a habit of expressing hardships through joking. The meaning of family was great for the Vietnamese. Speaking ill of one's own family was not customary. It was typical that [Vietnamese] people working abroad sent money to their relatives back in their home country."

(Court verdict, p. 128)

Later in the verdict (p. 132) it is also mentioned that "In Vietnamese culture, according to witness $\mathrm{XX}$, it is typical that emotions are not expressed openly." On the next page, this is clearly taken as a truth when the court states: 
“The credibility of the plaintiffs' statements increase when taking into consideration that many of them have shown emotions when answering questions regarding their working hours or the extreme nature of the labour even when this is not typical in Vietnamese culture."

(Court verdict, p. 133)

As mentioned earlier, the witness was not the only source of cultural information in the case as the cultural arguments presented by the defendants and plaintiffs (or their lawyers) also received recognition. However, it seems that as the defendants and plaintiffs are by definition biased in a case that concerns themselves, the court seeks to verify their arguments through the agency of a less involved party. In this endeavour, the witness ended up playing a meaningful role, which is also demonstrated in the following paragraph:

"The defendants, plaintiffs as well as the witness $X X$ have consistently explained that all Vietnamese people working abroad send money to relatives in their home country. A Vietnamese person who goes abroad to work cannot without the risk of losing face refrain from sending money to their home country."

(Court verdict, p. 143, emphasis added)

\section{Interpreters as invisible cultural experts}

In the trials I attended, the role played by interpreters turned out to be substantial. Often, members from cultural minorities, most of whom were immigrants, did not have sufficient Finnish language skills and, hence, required interpreting. An interpreter who I interviewed explained to me that ideally she and her colleagues should appear invisible — as neutral tools who enable communication but who do not otherwise intervene in the process. Often, as was also acknowledged by the interpreter, this fails to be the case. 
The academic literature on court interpreters, likewise, stresses the crucial yet highly problematic position of an interpreter, who is often confronted with legal actors' naïve expectations for performing "as a disembodied mechanical device" (Wadensjö 1998: 74, see also Colin and Morris 1996: 17-18, Gibb and Good 2014, González et al. 1991: 314, Morris 1995; 2010, Rycroft 2011: 209). Scholars who have studied interlingual interpreting in refugee status determination procedures and other legal settings, have found the myth of verbatim, or word-for-word, translation particularly prevailing (Colin and Morris 1996: 17, Gibb and Good 2014: 389, 394, Morris 1995; 2010: 59). As noted by Morris (1995: 30-31) this "legal fiction" on absolute accuracy of translation, works in the favour of the law allowing it to ignore the inevitable failure of the interpreting process "to reproduce an identical replica across the language barrier". The interpreters are, then, assumed to operate anonymously in a sort of socio-cultural vacuum despite them occupying highly active and multifaceted roles in the institutional reality.

A prosecutor who I interviewed was worried about, what she understood as, the varied professional skills of different interpreters. She had a lot of experience in working with immigrants, and she strongly opposed the tendency of some interpreters to "explain rather than just translate" what has been said. The idea of word-for-word translation received strong support from her as she explained to me that the choices of words and order of questions played a crucial role in her work. The prosecutor did, however, recognise the mixed expectations set for interpreters when she stated:

"Sometimes they [interpreters] are entirely misused in trials. They might be asked "is that really how it is'? And that's where it goes horribly wrong."

(Interview, prosecutor)

The interpreter I interviewed was, hardly surprisingly, well aware of their position in the middle of varied expectations and assumptions. She explained how it frequently felt as though some people in the courtroom assumed her to be on someone else's side, which meant that she had to often remind 
all the parties of the trial about her unbiased position, think about seating arrangements and avoid extensive eye contact. She recounted an instance where some immigrant defendants saw a police officer whisper something to her during a trial and hence started to assume that the interpreter worked for the police. In another case, a prosecutor wanted to know what two defendants had talked about during a break and stressed to the interpreter: "you are our interpreter, you have to translate everything". The interpreter said that she was irritated by the comment and told the prosecutor that, first of all, she was no one's interpreter, regardless of who pays her, and second of all, it was not her job to remember things during the trial or when she was taking a break.

It seems that interpreters are often expected to have a naturally strong connection to the cultural minority defendants or plaintiffs involved in the case (see also Morris 1999: 9-10), and are trusted in explaining issues relating to the language as well as culture they are all assumed to share. During one trial I participated in, there occurred a mundane and short, yet quite telling, discussion around two names that kept appearing in a witness's narrative. Due to the large number of defendants, seven altogether, there were two interpreters present throughout the trial, and they worked together closely:

Judge: The names Ahmed and Ahmad keep appearing in the story, which one is right?

Interpreter A: Is the question for the interpreter or for the witness?

[Judge remains quiet]

Witness: [says something in Kurdish]

Interpreter A: [explains in general terms in Finnish about the two ways to spell and use the name]

Interpreter B: To clarify, that was the interpreter's own view, the witness said that he doesn't know and in his area they just use Ahmed and he doesn't know how it is spelled.

(Court notes) 
Discussions similar to the one above are, in my experience, common. Whenever an interpreter has offered their own explanation to an unclear issue, I have not noticed any opposition or resistance to accept it from other parties of the litigation. On the contrary, the 'cultural interpretation' is often welcomed and, as already mentioned earlier, even sought after. When I asked the interpreter (Interpreter B in the above example), if she was ever asked to clarify cultural matters she responded:

"Yes, sometimes they do ask. But at times I see it as necessary to say something if I can tell that the other one has not understood and then I say that 'interpreter comments' and then explain the matter and interpret the same explanation also into the other language. It does help and in that way we can avoid questions that last for ten minutes."

(Interview, interpreter)

Indeed, it appeared to be beneficial for everyone involved in the trials when the interpreters intervened and helped the process by offering their own interpretation of the situation. This was likewise the case in a trial where an interpreter explained to the Finnish legal professionals why a witness wished to swear an oath by the name of God rather than give a non-religious affirmation. ${ }^{1}$ In another case, the cultural minority defendants' statements, six of them, would have appeared a lot more confusing if the interpreter had not explained that when they talked about their 'brothers' they, in reality, referred to their close friends instead of biological family members. All in all, in the cases I studied, it seemed as though the interpreters were utilised as unofficial cultural mediators due to their neutral position and legal status. Consequently, they were relied on in explaining cultural

\footnotetext{
${ }^{1}$ As a result of the 2016 reform concerning the law of evidence, religious oaths are no longer in use in Finnish courts of law, but the witnesses are required to give an affirmation (Rautio and Frände 2016: 272).
} 
differences that helped to clarify the communication in the courtrooms, but they had to remain invisible in the final verdicts.

Lawyers, prosecutors and courts themselves as the providers of cultural information

When I heard cultural arguments being raised in criminal trials, they were most often presented by defence lawyers, although on one occasion also by a prosecutor. In one case, a defence lawyer highlighted that due to the extremely subordinated status of their female client originating from Afghanistan, the blame on financial fraud should not fall on her shoulders but solely on her husband's, who was in charge of all the household finances during their marriage. In the same case, the prosecutor undermined the cultural arguments by stressing that the defendant had, for example, abandoned the use of the veil and was not to be victimised. Regardless of the significant amount of 'culture talk' during the trial, no comments on 'culture' featured in the written verdicts. Indeed, and as indicated earlier, it seems that the courts are reluctant to quote the lawyers' or prosecutors' statements on culture unless they are verified by a seemingly unbiased party or other source of evidence.

The sources of cultural arguments are, then, many in criminal trials, but when quoted in the final verdicts, their origins can also remain unclear. Indeed, it appears that the court can rely on its own authority when making statements about culture - a realm that is ordinarily not regarded as their area of expertise. Here is a quote from the earlier mentioned case regarding human trafficking and forced labour in Oriental restaurants:

"The Court of Appeal finds also that the threat of being sent back [from Finland to Vietnam] is connected to the so-called risk of losing face, as in Vietnamese culture it is the duty of a man to provide for both his immediate family as well as his close relatives. Likewise, the shame resulting from an employer terminating the 
employment relationship works as a threat in a culture where respecting one's employer, or generally someone who is higher in the hierarchy, is central."

(Court verdict, p. 7)

Even when reading the above quote in the original context, it is impossible to deduce what or whose knowledge is utilised. It is possible that the court relies on something one of the lawyers, even the prosecutor or perhaps the Finnish-Vietnamese witness said during the trial, but that is not pronounced clearly as it stands. Presently, the sole basis for the 'cultural expertise' utilised in the statement appears to be found in the Court of Appeal itself. It is difficult to avoid the impression that the court members have relied on their own existing views which, at worst, have stemmed from stereotypes.

\section{Making invisible}

It seems to me that when the law courts addressed culture in the verdicts I studied, their tendency was to either mask the cultural arguments to appear as part of something different from expert knowledge or to make the source of the information anonymous. As a result, the cultural arguments provided by the eyewitnesses were seen as part of their testimony as witnesses who were under oath and not as insight introduced by specially invited experts. In practice, this meant that the eligibility requirements set out for experts utilised in law courts were not applied to the witnesses who, nevertheless, ended up serving as cultural experts. According to the requirements, an expert has to be deemed honest and accomplished in their field, in addition to which they have to remain impartial with regard to the matter and people in question (Criminal Procedure Act, chapter 17, $35 \S)$. In practice, as the courts did not treat the informal cultural experts as legally recognised experts, they ended up being less critical towards the cultural information provided by them. 
According to my view, the discursive practices utilised by the courts in the legal documents played a key role in allowing them to apply informal cultural expertise. Studying court documents as cultural artefacts that create meanings and social reality (cf. Merry 1992, Riles 2006) helps in highlighting the significance of these discursive practices deployed by the courts. The relationship between language and law is undeniably a fundamental one as the concepts that are central to our legal systems, such as 'guilt' or 'murder', are accessible to us only through language (Gibbons 1994: 3). Legal discourses, for example, fabricate the categories of persons and things (Pottage and Mundy 2004) and, arguably, can even end up revictimising women who prosecute their assailants in rape trials (Conley and O’Barr 2005: 15-38).

Perhaps the most troubling strategy the courts seemed to utilise in applying informal cultural expertise was to make the sources of the information anonymous. This was particularly noticeable in the legal documents that the law courts provided themselves. The language that the courts used in the official documents favoured the passive voice. Phrases such as "it has been told" (quote on p. 8) or "in the hearing it has been noticeable that" or "it can be deduced that" (Court verdict on human trafficking and forced labour, p. 132) were in common use in the documents produced by the courts. Such language problematically hides the social actors behind the arguments making it impossible to reliably locate the original sources of information that the courts relied on.

The way in which the courts referred to themselves in the third person appeared to me as another technique to conceal distinct agency. Depending on the case and the level of the law court, 'the court' consisted of three to four people that, in District Courts, included lay judges in addition to one professional judge, and in the Courts of Appeal involved only professional judges. In spite of the courts' inevitable internal dissimilarity, their views were manifested in the verdicts only through one voice: "The court deems" (quote on p. 8), "The Court of Appeal finds" (quote on p. 14), "The Court of Appeal sees similarly to the District Court", "The Court of Appeal states additionally that" (Court verdict on human trafficking and forced labour, p. 7). 
The quotes mentioned above come across as particularly peculiar after reading the last few pages of the verdict from the case concerning human trafficking and forced labour. The case evidently posed challenges for the Court of Appeal, and they were, in fact, unable to reach consensus on the issue without voting. One of the three judges had a more lenient interpretation of the events and he would have abandoned the charges of human trafficking. As the two other judges, however, understood the indictment as justified, the defendants were found guilty of the crime. The judge who disagreed, had to make a record of his differing views at the end of the verdict document, but that remained the only place where the internal disharmony of the court became visible. Throughout the document 'the Court of Appeal' is presented as a singular and undivided entity, when in reality it primarily reflected the views of two, not three, of the judges. Arguably, as the legal verdicts tended to mask the sources of cultural information and refer to the court as an impersonal collective, they built towards a view of the court as an omniscient and objective authority. This view naturally facilitated legitimacy for the benefit of the courts, but it disguised the persons behind the views making it difficult to direct scrutiny towards the right party, be it a court member, interpreter, lawyer or prosecutor.

\section{Making visible}

In order to avoid the obscurity regarding the cultural information now utilised by the courts in their verdicts, the textual practices applied should be transparent enough to allow the tracing of cultural arguments back to their presenters. It should perhaps be noted here that the textual practices which hide the multivocality of the law court are, of course, not only applied when it comes to culture. Enforcing the univocal rhetoric might be a wider problem of the legal discourse in general although my focus has been on 'culture talk' in particular. Avoiding the use of passive voice whenever possible as well as refraining from alluding to a group of people as a singular entity, seem to me like appropriate methods to start addressing the issue of making cultural information anonymous. A 
possible step further could be to start looking into ways of formalising cultural expertise. A move from informal cultural expertise towards a more transparent and recognised form of cultural expertise appears desirable in an environment where 'culture talk' is, no matter what, present. Yet, a difficult question regarding the legitimacy and credibility of cultural expertise remains: who could be seen as a reliable cultural expert?

\section{Insider experts}

The people who, according to my interpretation, ended up providing the court with cultural expertise in the cases discussed above were not doing that from the position of recognised cultural experts but rather they already had distinct roles in the trials as witnesses and interpreters.

Occasionally the courts appeared to extend their job descriptions and, in essence, perceived them as community members providing information regarding 'their culture'. Does this necessarily pose a problem, however, if the brokers can be regarded as sharing the same cultural minority background with the defendants and/or plaintiffs?

There has been scholarly discussion on who could be seen as best qualified to provide the court with cultural expertise: a professional expert, such as an anthropologist, or a community member (cf. Caughey 2009: 326, Holden 2011b: 209-210, Renteln 2004: 206). Having insiders explain their traditions can arguably appear "more politically palatable" (Renteln 2004: 206), yet it seems problematic for courts to assume that community members can automatically be employed as experts without any training, solely based on traits such as their ethnic identity (cf. Holden 2011b: 209-210). As John Caughey (2009: 326) points out, one can “speak a language fluently without being a convincing expert on its linguistic structure." In the case involving Vietnamese defendants and plaintiffs, for example, it is worth considering to what extent the Finnish-Vietnamese witness could be regarded as their 'spokesperson' in cultural matters more generally. The witness had lived her life almost entirely in Finland, in addition to which her age, gender and socioeconomic status 
seemed to set her apart from the majority, if not all, of the other people with Vietnamese backgrounds involved in the case. Despite this, her statements regarding Vietnamese culture were treated in many ways as the objective descriptions of a culture that they all were assumed to share.

In Mr Amin's case there seemed to be fewer obvious differences between the witness, the plaintiff and the defendant. However, even though the witness was assumed to share the same cultural minority background with the defendant and the plaintiff, it did not necessarily make him the most reliable cultural expert. The witness' statement quoted in the verdict on religion being something in 'their culture' that one can insult, for example, might very well reflect the views of a secularised Kurd, but assuming that this would characterise 'their culture' more broadly, appears highly dubious. This accepted cultural argument might have not impacted Mr Amin's legal case, as perhaps he did share the same views regarding religion, yet relying on such generalisations more commonly in a legal terrain certainly appears problematic.

According to my data, when interpreters were used as cultural brokers in courts, the issues were often small in scale and had to do with solving problems relating to communication. On several occasions, it appeared to be beneficial for everyone in the courtroom when the interpreters shed light on cultural matters that went beyond mere linguistic interpreting. Given the criticism pointed to verbatim translation (e.g. Colin and Morris 1996: 17, Gibb and Good 2014: 394, Morris 1995: 27; 2010: 59), the expectations according to which such 'mere linguistic translation' is even possible, appear unfounded at any rate. The role of an interpreter as a visible actor who seeks to interpret and convey the meanings of what has been said should be stressed over the idea of the interpreter as a neutral conduit (Gibb and Good 2014: 396, Morris 1995: 25). It can be further argued that due to the close connection of culture and language, interpreters acting as cultural brokers is even inevitable to some extent. Indeed, drawing a clear line between lingual and cultural interpreting seems impossible at times. 
Despite the inevitable intertwining of lingual and cultural interpreting, there are situations in which the line between the two should be made more distinct. Similar limitations that concern employing witnesses as cultural experts can also apply here. The backgrounds of the interpreters, who according to my experience often have a long history of living in Finland, potentially set them fairly far apart from the people they interpret. Also, the interpreter and the defendant and/or the plaintiff sharing the same language hardly indicates that they necessarily have a connection to the same country or culture. Needless to say, one interpreter can work in multiple languages regardless of their home country, ethnicity or cultural background. It is worth mentioning that, so far, I have only met one interpreter working in court who was a native Finnish speaker, all the others being native in the minority language they interpreted.

A prosecutor I interviewed pointed out that on some occasions she wonders if the possible nonprofessional relationship between the interpreter and the defendant and/or the plaintiff has an effect on the interpreting. She mentioned a case where the cultural minority defendant took objection to employing a female interpreter in a case concerning their purchase of sexual services. The prosecutor also wondered about the possible impact of other personal attributes, such as religion, on the interpreting process:

"If I have two Sorani speakers [in court] and one is Shia and the other one Sunni, then is it possible for the Shia to interpret the Sunni? Will the Sunni be able to give the account they should be able to give or are they afraid to speak, or does the story change or is the problem just in my head?"

(Interview, prosecutor)

The interpreters have a legally neutral position in trials and, as the interpreter I interviewed highlighted, they can even go to great lengths in terms of arranging seating and avoiding extensive eye contact, in order to secure their impartiality. Diana Morgan (1982: 51) and Ruth Morris (1999: 
10-11) have, likewise, highlighted the significance of the physical setting for the interpreterdefendant relationship. Yet, and as has been demonstrated already earlier, different parties to the trial can have doubts and assumptions regarding the neutral status of interpreters. Interpreters are in a powerful position in trials as they are the only ones in the room who understand all the parties. Interpreters are heavily relied on throughout the trial and suspicions regarding the influence of their personal views or socio-cultural stance on the case can understandably cause uneasiness. Drawing the line between lingual and cultural interpreting more distinct (whenever possible) as well as being more transparent regarding the interpreter's background could prove useful. When an interpreter analyses a situation or explains further why, for example, a defendant acts in a certain way or uses particular vocabulary, they should make it apparent that they are relying on their personal view and experience and not offering an objective description of any singular 'culture'.

\section{Trained experts and the potential of cultural expertise}

There appears to be several limitations in utilising community members as cultural experts in legal cases involving members from cultural minorities, which leads into considering the potential of employing experts who are academically trained in specific cultural matters or geographical regions. In the cases I studied, no trained experts were utilised. Is it possible, however, that employing cultural expertise offered by trained specialists would have made a difference in the cases through, for example, challenging some of the notions regarding cultures that seemed simplified? Trained experts might indeed have the potential of converting the informal 'culture talk' of courtrooms into negotiations that are more explicit and formalised in nature. It is possible to further reason, however, that using 'trained experts' such as anthropologists to provide cultural expertise comes with questionable baggage of its own. The differences between legal and anthropological knowledge - the former dealing with absolutes while the latter is more intertwined with the idea of relativity-mean that anthropological expertise does not easily receive recognition 
in the legal environment in the first place (e.g. Fontein 2014, Good 2008). The reflective and lengthy academic style might not align itself effortlessly with the legal approach in which the focus is on fact finding and resource (time and money) efficiency (cf. Bouillier 2011: 69, Good 2011: 99, Holden 2011b: 204).

Anthropologists or other 'trained experts', then, are unlikely to share the same language or style of reasoning with legal practitioners, in addition to which, they too (as can be the case with community members) are faced with claims relating to advocacy (Holden 2011b: 210-211, Menski 2011, Vatuk 2011: 29-30). Even when the ideal expert witness, at least from a court official's point of view, remains detached and impartial with regard to all the parties to the legal proceeding at issue, the reality often proves to be ethically quite slippery. Sylvia Vatuk (2011: 30) has aptly highlighted how by choosing a potential expert witness from a pool of academics oriented towards a specific regional area, one is more likely than not to engage with a person "already favourably inclined to sympathise with the aspirations of immigrants". Indeed, the boundary between cultural expertise and advocacy is a blurry one, and, as Vatuk (p.30) concludes, "it is not easy to remain dispassionate and, as a result, the risk of being caught in a conflict of loyalties is very real."

Perhaps the most demanding challenges with cultural expertise, no matter who is the provider, relates to conceptualising culture. It can be argued that modern statecraft favours simplifications of societal activities and phenomena that are not even intended to represent the complex reality, but only the slice of it that intrigues the official observer (cf. Scott 1989: 3). Culture has to be tailored to fit the "bureaucratic formulae" (Scott 1998: 22), which inevitably leads into an uncomplicated view of culture where all the rough corners of a complex social construct have been rounded. Indeed, it appears that the legal sphere gives support to particularly essentialist presentations of cultural minority identities (Coffman 2007, Demian 2008, Good 2008, McKinley 2009). This was demonstrated also in my data when, for example, the District Court suggested in their verdict concerning Mr Amin's case that the defendant and plaintiff are both Kurds who share the same 
cultural background (quote on p. 8). This was their conclusion despite the fact that at no point during the two hearings detailed questions regarding the men's background were asked. It can be argued that by providing 'an expert view' on what constitutes a tradition, cultural identity or even $a$ culture, the experts too would inevitably reinforce an imagery prone to essentialist features (cf. Good 2008: 56-57). The two options then, to either reify or nullify culture, must seem equally unattractive to most potential experts giving rise to conflicting views with regard to the possibility of cultural expertise overall (Demian 2008, Renteln 2004, Van Broeck 2011, Wikan 1999).

Cultural expertise might appear to be legally difficult to digest, while the potential experts themselves can find harnessing cultural enquiry into legal purposes ethically disturbing. The scholars who have immersed themselves in the study of a specific cultural area or a group, not forgetting the community members themselves, might feel it least burdensome to shun all legal involvement, yet the opposite conclusion is equally conceivable. But maybe, after all, "Law is too important to be left solely to lawyers" (Good 2008: 57) and it could even be regarded as the trained expert's or community member's moral obligation to share their cultural understanding when there are high stakes legal decisions in question involving cultural issues (cf. Caughey 2009: 323). Cultural expertise also has the potential of addressing the opportunistic uses of culture and thereby help in ensuring that cultural argumentation is not misused (cf. Caughey 2009: 324).

In the cases I studied, the potential of cultural expertise provided by trained experts was not tested, yet I believe it could have had a beneficial effect on the discussions around cultures that did take place. A trained expert, with no personal connection to any of the parties involved in the case, could have played a role in providing information regarding cultural issues that was more impartial than when presented by an involved eyewitness, for example. The involvement of a trained expert could have also worked as a sort of eye opener for other parties connected to the case regarding the existence and significance of 'culture talk' in the legal sphere. Perhaps the authors of court verdicts 
would have considered the origins and meanings of cultural arguments more carefully, and consequently, also adapted their textual practices in legal documentation accordingly.

\section{Conclusions}

In order to increase the likelihood of justice in trials, the invisible cultural expertise of Finnish courtrooms should be made more explicit. From a legal perspective, which I am not an expert on, it appears troublesome if a person who is formally not recognised as an expert witness comes to be treated as one. This chapter, however, is not an attempt to engage in that legal discussion. Interpreters and eyewitnesses, according to my data, can be used as informal cultural experts regardless of their official status or the possible legal restrictions. Also, the courts themselves can act as sources of cultural information without providing further rationale for their arguments, as has been demonstrated earlier. The 'cultural expertise' that is now being utilised, then, can be overly simplistic, rely on stereotypes or even turn out biased. Additionally, when informal cultural experts are utilised in a haphazard manner, too much is left to chance. The risk is that a cultural minority defendant or plaintiff would only benefit from (or be harmed by) 'cultural expertise' when there are suitable interpreters or eyewitnesses involved in their legal case.

The interpreters are legally neutral and the eyewitnesses are under oath, which arguably makes them appear more trustworthy in the eyes of the court when compared to, for example, the defendants who are not obligated to tell the truth. Additionally, the interpreters and witnesses who were utilised in the cases I studied, seemed to have 'a cultural connection' to the defendants and/or plaintiffs through, for example, a shared language or home country. Interestingly, in these cases there were also indications of the significance of certain bodily strategies in constructing credible expertise. As mentioned earlier, the witness in Mr Amin's case performed in a calm and assertive manner in the courtroom, and the interpreter I interviewed, talked about the attention she had to pay 
to seating arrangements and eye contact. Arguably, these ways of being and performing built towards their appearance as honest and dependable in the eyes of the law court. It appears, then, that in the process of constructing expertise it is not only the talk and 'cultural connection' that count, but also the ways of being in one's body in a specific space.

The discursive techniques applied by the authors of court verdicts tended to hide the roots of the cultural arguments presented in the legal cases, which arguably worked in the favour of the court's own legitimacy. Paying more attention to such textual practices is the first step in making 'culture talk' more transparent in the legal field. Introducing formal cultural expertise into the courtrooms could be the logical next step. This does evidently present some challenges and further avenues for study in order to resolve not only how cultural expertise could be utilised, but also who should be the ones providing it.

The decision of some potential experts to avoid any legal involvement is understandable, yet leaving 'culture talk' solely in the hands of lawyers, court officials and informal cultural experts is hardly desirable (cf. Good 2008). An insider's account can prove to be extremely valuable while a 'trained expert' might be better equipped to highlight culture's importance to human behaviour and thoughts in general, as well as to articulate this knowledge to wider audiences and support it with scholarly references (Caughey 2009: 326). Employing cultural expertise does pose challenges, yet 'trained experts' together with community members might well have the potential of addressing overly simplistic notions on cultures and help in spotting the instances when cultural arguments are also being abused. In Finland and elsewhere, the ever widening range of cultural identities is now a prominent feature of courtrooms, and they are constantly being discussed and assessed—with or without experts' involvement. 


\section{Acknowledgements}

I thank my supervisors Hannu I. Heikkinen and Sami Lakomäki for their invaluable contribution to this article.

\section{References}

\section{Court cases}

Attempted manslaughter, 2016 (Verdict R16/ZZZ)

Human trafficking and forced labour, 2012 (Verdict R12/YYY)

Interviews

Prosecutor, 26.10.2016

Lawyer, 1.2.2017

Interpreter, 30.1.2017

\section{Bibliography}

Ballard, R. (2011). Honour Killing? Or Just Plain Homicide? In Holden, L. (ed.) Cultural Expertise and Litigation: Patterns, Conflicts, Narratives. London, Routledge, pp. 123-148.

Bouillier, V. (2011). French Law Courts and South Asian Litigants. In Holden, L. (ed.) Cultural Expertise and Litigation: Patterns, Conflicts, Narratives. London, Routledge, pp. 5370.

Bronitt, S. (2009). Visions of a Multicultural Criminal Law: an Australian Perspective. In Foblets, M. C. and Renteln, A. D. (eds.) Multicultural Jurisprudence: Comparative Perspectives on the Cultural Defense. Oxford, Hart Publishing, pp.121-144. 
Carstens, P. A. (2009). The Cultural Defence in Criminal Law: South African Perspectives. In Foblets, M. C. and Renteln, A. D. (eds.) Multicultural Jurisprudence: Comparative Perspectives on the Cultural Defense. Oxford, Hart Publishing, pp.175-195.

Caughey, J. L. (2009). The Anthropologist as Expert Witness: the Case of a Murder in Maine. In Foblets, M. C. and Renteln, A. D. (eds.) Multicultural Jurisprudence: Comparative Perspectives on the Cultural Defense. Oxford, Hart Publishing, pp. 321-334.

Coffman, J. E. (2007). Producing FGM in U.S. Courts: Political Asylum in the Post-Kasinga Era. Africa Today 53(4):59-84.

Colin, J. and Morris, R. (1996). Interpreters and the legal process. Winchester, Waterside Press.

Conley, J. M. and O'Barr, W. M. (2005). Just Words: Law, Language, and Power ( $2^{\text {nd }}$ edition). Chicago, The University of Chicago Press.

Demian, M. (2008). Fictions of Intention in the "Cultural Defense". American Anthropologist $110(4): 432-442$.

Fontein, J. (2014). "She appeared to be in some kind of trance": Anthropology and the question of unknowability in a criminal trial. HAU: Journal of Ethnographic Theory 4 (1): 7-103. Retrieved from: https://www.haujournal.org/index.php/hau/article/view/hau4.1.003

Gibb, R. and Good, A. (2014). Interpretation, translation and intercultural communication in refugee status determination procedures in the UK and France. Language and Intercultural Communication 14(3): 385-399.

Gibbons, J. (1994). Introduction: language constructing law. In Gibbons, J. (ed.) (1994) Language and the Law. London, Routledge, pp. 3-10.

González, R. D., Vásquez, V. and Mikkelson, H. (1991). Fundamentals of Court Interpretation: Theory, Policy, and Practice. Durham, Carolina Academic Press. 
Good, A. (2008). Cultural Evidence in Courts of Law. Journal of the Royal Anthropological Institute 14(1):S48-S60.

Good, A. (2011). Witness Statements and Credibility Assessments in the British Asylum Courts. In Holden, L. (ed.) Cultural Expertise and Litigation: Patterns, Conflicts, Narratives. London, Routledge, pp. 94-122.

Heinämäki, L., Allard, C., Kirchner, S., Xanthaki, A., Valkonen, S., Mörkenstam, U., ... Olsen, L. (2017). Saamelaisten oikeuksien toteutuminen: kansainvälinen oikeusvertaileva tutkimus. Valtioneuvoston selvitys- ja tutkimustoiminnan julkaisusarja 4/2017. Retrieved from: http://tietokayttoon.fi/documents/10616/3866814/4_Saamelaisten+oik euksien+toteutuminen+kansainv\%C3\%A4linen+oikeusvertaileva+tutkimus/e765f819d90c-4318-9ff0-cf4375e00688?version=1.0

Holden, L. (ed.) (2011a). Cultural Expertise and Litigation: Patterns, Conflicts, Narratives. London, Routledge.

Holden, L. (2011b). Expert Report Writing: Professional Commitments and Legal Outcomes. In Holden, L. (ed.) Cultural Expertise and Litigation: Patterns, Conflicts, Narratives. London, Routledge, pp. 195-211.

Husa, J. (2012). Panorama of World's Legal Systems: Focusing on Finland. In Nuotio, K., Melander, S. and Huomo-Kettunen, M. (eds.) Introduction to Finnish Law and Legal Culture. Helsinki, Faculty of Law, University of Helsinki, pp. 5-18.

Kokko, K. (ed.) (2010). Kysymyksiä saamelaisten oikeusasemasta. Rovaniemi, University of Lapland. Retrieved from: https://www.ulapland.fi/loader.aspx?id=becc9ced-66ae4755-83c4-d594e099eada

McKinley, M. (2009). Cultural Culprits. Berkeley Journal of Gender, Law \& Justice 24(2):91-165. 
Melander, S. (2012). Criminal Law. In Nuotio, K., Melander, S. and Huomo-Kettunen, M. (eds.) Introduction to Finnish Law and Legal Culture. Helsinki, Faculty of Law, University of Helsinki, pp. 237-247.

Menski, W. (2011). Life and Law: Advocacy and Expert Witnessing in the UK. In Holden L (ed.) Cultural Expertise and Litigation: Patterns, Conflicts, Narratives. London, Routledge, pp. 151-171.

Merry, S. E. (1992). Culture, Power, and the Discourse of Law. New York Law School Law Review, 37:209-225.

Morgan, D. (1982). The life of a court interpreter. Graya 86:51-52.

Morris, R. (1995). The Moral Dilemmas of Court Interpreting. The Translator 1(1):25-46.

Morris, R. (1999). The gum syndrome: predicaments in court interpreting. Forensic Linguistics 6(1): 6-29.

Morris, R. (2010). Missing stitches: An overview of judicial attitudes to interlingual interpreting in the criminal justice systems of Canada and Israel. In Pöchhacker, F. and Shlesinger, M. (eds.) Doing Justice to Court Interpreting. Amsterdam, John Benjamins Publishing Co.

Noll, G. (2006). Asylum Claims and the Translation of Culture into Politics. Texas International Law Journal 41:491-501.

Pottage, A. and Mundy, M. (eds.) (2004). Law, anthropology, and the constitution of the social: making persons and things. Cambridge, Cambridge University Press.

Rautio, J. and Frände, D. (2016). Todistelu: Oikeudenkäymiskaaren 17 Luvun Kommentaari. Helsinki, Edita. 
Riles, A. (2006). Documents unfolding. In Riles, A. (ed.) Documents: Artefacts of Modern Knowledge. Ann Arvor: University of Michigan Press, pp. 158-180.

Renteln, A. D. (2004). The Cultural Defense. New York, Oxford University Press.

Rycroft, R. (2011). Hidden Penalties Faced by Non-English Speakers in the UK Criminal Justice System: An Interpreting Perspective. In Cheng, L. and Wagner, A. (eds.) Exploring Courtroom Discourse: The Language and Power and Control. Farnham, Ashgate Publishing Group.

Scott, J. C. (1998) Seeing Like a State: How Certain Schemes to Improve the Human Condition Have Failed. New Haven, Yale University Press.

Spijkerboer, T. (2005). Stereotyping and Acceleration: Gender, Procedural Acceleration and Marginalised Judicial Review in the Dutch Asylum System. In Noll, G. (ed.) Proof, Evidentiary Assessment and Credibility in Asylum Procedures. Leiden, Martinus Nijhoff, pp. 67-102.

Van Broeck, J. (2001). Cultural Defence and Culturally Motivated Crimes. European Journal of Crime, Criminal Law and Criminal Justice 9(1):1-31. Retrieved from: http://ww.jthomasniu.org/class/781/Assigs/vanbroeck-cultdef.pdf

Vatuk, S. (2011). South Asian Muslims and Country Expertise in the American Immigrant Courts. In Holden, L. (ed.) Cultural Expertise and Litigation: Patterns, Conflicts, Narratives. London, Routledge, pp. 13-34.

Wadensjö, C. (1988). Interpreting as interaction. London and New York, Longman.

Wikan, U. (1999). Culture: A New Concept of Race. Social Anthropology 7(1):57-64.

Winkelman, M. (1996). Cultural Factors in Criminal Defence Proceedings. Human Organisations 55(2):154-159. 